\title{
Derajat Aglutinasi Pemeriksaan Golongan Darah Metode Cell Grouping Berdasarkan Tingkat Konsentrasi Suspensi Sel
}

\section{Degree of agglutination of blood group examination Cell Celling Method Based on Cell Suspension Concentration Level}

\section{NUR MUHJAH KHOODIJAH NURUL QOMARIYAH}

\author{
Jurusan Analis Kesehatan Poltekkes Kemenkes Semarang \\ Jl. Wolter Monginsidi Pedurungan Tengah Semarang \\ E-mail: choiahneul@gmail.com
}

\begin{abstract}
Abstrak
Transfusi darah harus melalui prosedur yang ketat untuk mencegah efek samping reaksi transfusi. Salah satu prosedur yang harus dijalani adalah penentuan golongan darah ABO dan Rhesus. Kadar dari antigen dan antibodi berperan dalam pembentukan aglutinasi. Semakin banyak antigen-antibodi yang berikatan, akan membentuk aglutinasi yang semakin besar, jelas, dan semakin kuat. Menganalisa perbedaan derajat aglutinasi pemeriksaan golongan darah metode cell grouping berdasarkan tingkat konsentrasi suspensi sel. Jenis penelitian yang digunakan adalah penelitian eksperimental. Subjek penelitian sejumlah 18 mahasiswa dikelompokkan berdasarkan golongan darah A, B dan AB. Setiap suspensi sel diberi perlakuan menjadi suspensi sel konsentrasi 5\%, 10\%, 15\% dan 20\%. Semua hasil pemeriksaan menunjukkan derajat aglutinasi $4+$. Suspensi sel konsentrasi 5\%, 10\%, 15\% dan $20 \%$ pada pemeriksaan golongan darah A dan B menghasilkan data yang sama yaitu derajat aglutinasi $4+$ dengan latar belakang yang jernih. Suspensi sel konsentrasi 5\% pada pemeriksaan golongan darah $\mathrm{AB}$ membentuk derajat aglutinasi 4+ dengan latar belakang lebih jernih sebanyak 70\%.
\end{abstract}

Kata Kunci: Golongan Darah ; Cell Grouping ; Konsentrasi Suspensi Sel ; Derajat Aglutinasi

\begin{abstract}
Blood transfusions must go through of strict procedures to prevent transfusion reactions that can appeared. One procedure that must be do is the examination of $A B O$ and Rhesus blood group. Ratio of antigens and antibodies play a role in the formation of agglutination. The more bonded antigens-antibodies, the larger, clearer, and stronger the agglutination will be. Analyzing the different of degree of agglutination of blood examination cell grouping method based on cell suspension concentration level. The type of research used is experimental research. The subjects of the study were 18 college students were grouped by blood group $A$, $B$ and $A B$. Each cell specimen was treated to make cell suspension concentration of 5\%, 10\%, $15 \%$ and $20 \%$. All examination result show degree of agglutination $4+$. The cell suspension concentration of $5 \%, 10 \%, 15 \%$ and $20 \%$ in blood type $A$ and $B$ examination show the same data that's degree of agglutination $4+$ with clear background. The cell suspension concentration of 5 in blood type $A B$ examination show degree of agglutination $4+$ with clear background of $70 \%$.
\end{abstract}

Keyword: Blood Examination ; Cell Grouping ; Cell Suspension Concentration ; Degree of Agglutination 


\section{Pendahuluan}

Pelayanan transfusi darah merupakan upaya pelayanan kesehatan yang meliputi perencanaan, pengerahan dan pelestarian pendonor darah, penyediaan darah, pendistribusian darah, dan tindakan medis pemberian darah atau komponen darah kepada pasien untuk tujuan penyembuhan penyakit dan pemulihan kesehatan (Permenkes RI No.83, 2014; Bakta, 2012). Darah dan komponen darah dapat ditransfusikan secara terpisah sesuai dengan kebutuhan medis seperti kehilangan darah dalam jumlah besar yang disebabkan oleh trauma, operasi, syok dan tidak berfungsinya organ pembentuk sel darah merah (Budiningsih, 2010; PP No.7, 2011).

Transfusi darah harus melalui prosedur yang ketat untuk mencegah efek samping reaksi transfusi seperti hemolitik, dengan gejala seperti nyeri pinggang, nyeri kepala, nyeri dada, sesak nafas, muntah, menggigil, hipotensi, bahkan bisa terjadi hemoglobinaemia, bilirubinemia dan ikterus. Salah satu prosedur yang harus dijalani adalah penentuan golongan darah ABO dan Rhesus (Bakta, 2012).

Golongan darah merupakan pengklasifikasian darah dari suatu individu berdasarkan ada atau tidak adanya zat antigen warisan pada permukaan membran sel darah merah. Secara umum darah memiliki 4 golongan yaitu: golongan darah A yang memiliki antigen A dan antibodi $\mathrm{B}$, golongan darah $\mathrm{B}$ yang memiliki antigen $\mathrm{B}$ dan antibodi $\mathrm{A}$, golongan darah $\mathrm{O}$ yang tidak memiliki antigen tetapi memiliki antibodi $\mathrm{A}$ dan $\mathrm{B}$, dan golongan darah $\mathrm{AB}$ yang memiliki antigen A dan B tetapi tidak memiliki antibodi (Yuni, 2015).

Gold Standar untuk pemeriksaan golongan darah menurut World Health Organization (WHO, 2002) adalah dengan menggunakan metode tabung. Pemeriksaan golongan darah menggunakan metode tabung ada dua cara, yaitu serum grouping dan cell grouping. Cell grouping merupakan pemeriksaan golongan darah dengan cara sel darah merah pasien diperiksa dengan serum yang antibodinya telah diketahui untuk menentukan antigen pada sel eritrosit yang sedang diperiksa (WHO, 2013). Interpretasi dari hasil pemeriksaan golongan darah metode tabung berupa derajat aglutinasi.

Reaksi yang terjadi antara antigen dan antibodi akan membentuk suatu ikatan ditandai dengan munculnya aglutinasi. Reaksi aglutinasi terjadi jika antigen bertemu dengan antibodi yang sesuai. Kadar dari antigen dan antibodi berperan dalam pembentukan aglutinasi. Semakin banyak antigen-antibodi yang berikatan, akan membentuk aglutinasi yang semakin besar, jelas, dan semakin kuat reaksi yang terjadi (Faruq, n.d.). Maka semakin tinggi derajat aglutinasi yang terbentuk. Hal ini akan mempermudah dan mengefektifkan waktu petugas laboratorium untuk mengetahui apakah sampel terjadi aglutinasi atau tidak.

Pemeriksaan golongan darah metode tabung menggunakan suspensi sel yang dibuat dari eritrosit dan pelarut $\mathrm{NaCl} 0,9 \%$. Semakin tinggi konsentrasi suspensi sel yang dibuat, maka semakin banyak eritrosit di dalam suspensi sel itu, dan semakin tinggi pula kadar antigen di dalam suspensi selnya. Semakin tinggi kadar antigennya, maka semakin tinggi reaksi antigen dan antibodi yang dapat terjadi.

Tujuan penelitian ini adalah mengetahui adanya perbedaan derajat aglutinasi pemeriksaan golongan darah metode cell grouping berdasarkan tingkat konsentrasi suspensi sel.

\section{Metode}

Penelitian ini merupakan penelitian eksperimental dengan kriteria penelitian laboratorium yang dilakukan di Laboratorium Sementara Kampus III Poltekkes Kemenkes Semarang.

Penelitian ini menggunakan spesimen darah golongan $\mathrm{A}, \mathrm{B}$, dan $\mathrm{AB}$ yang direaksikan dengan reagen antisera $\mathrm{A}, \mathrm{B}$ dan $\mathrm{AB}$ merek Fortres.

Sebelum melakukan pemeriksaan dilakukan pembuatan kontrol negative dan kontrol positif. Kontrol negatif dibuat dengan cara mereaksikan golongan darah A dengan antisera B. 
Kontrol positif dibuat dengan mereaksikan golongan darah $\mathrm{AB}$ konsentrasi suspensi sel $100 \%$ dengan antisera $\mathrm{AB}$.

Pembuatan standar derajat aglutinasi juga dilakukan dengan cara mengencerkan reagen antisera yang akan digunakan. Cara pembuatan standar derajat aglutinasi :

a) Membuat derajat aglutinasi negatif. Reagen antisera B sebanyak $100 \mu 1$ direaksikan dengan darah A konsentrasi suspensi sel 10\% sebanyak $100 \mu 1$

b) 2.Membuat derajat aglutinasi $1+$. Reagen antisera $\mathrm{AB}$ sebanyak $50 \mu 1$ diencerkan dengan $\mathrm{NaCl}$ fisiologis sebanyak $1.500 \mu \mathrm{l}$ kemudian dihomogenkan, dan direaksikan dengan darah $\mathrm{AB}$ konsentrasi suspensi sel $10 \%$ sebanyak $50 \mu 1$.

c) 3.Membuat derajat aglutinasi $2+$. Reagen antisera $\mathrm{AB}$ sebanyak $50 \mu 1$ diencerkan dengan $\mathrm{NaCl}$ fisiologis sebanyak $1.200 \mu \mathrm{l}$ kemudian dihomogenkan, dan direaksikan dengan darah $\mathrm{AB}$ konsentrasi suspensi sel $10 \%$ sebanyak $50 \mu 1$.

d) 4.Membuat derajat aglutinasi 3+. Reagen antisera $\mathrm{AB}$ sebanyak $50 \mu 1$ diencerkan dengan $\mathrm{NaCl}$ fisiologis sebanyak $1.000 \mu \mathrm{l}$ kemudian dihomogenkan, dan direaksikan dengan darah AB konsentrasi suspensi sel 10\% sebanyak $50 \mu$ l. Menghasilkan derajat aglutinasi 3+.

Membuat derajat aglutinasi 4+. Reagen antisera AB sebanyak $100 \mu$ l direaksikan dengan darah $\mathrm{AB}$ dengan konsentrasi suspensi sel 10\% sebanyak $100 \mu 1$.

\section{Hasil dan Pembahasan}

Penderita Spesimen darah yang telah dibuat konsentrasi suspensi sel 5\%, 10\%, 15\% dan $20 \%$ kemudian dilakukan pemeriksaan golongan darah.
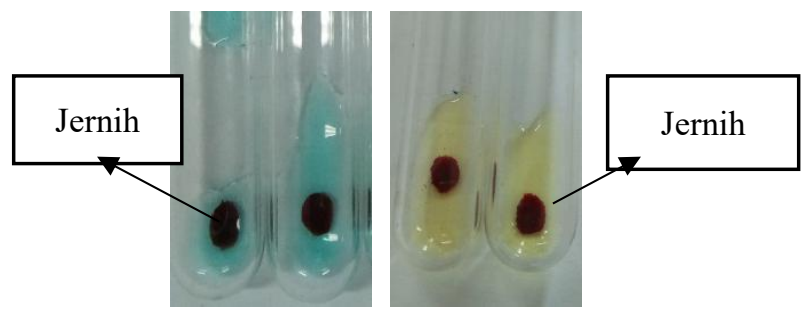

\section{Gambar 1. Pemeriksaan Golongan Darah A dan B dengan Latar Belakang Jernih}

Pada pemeriksaan golongan darah A dan B setelah dilakukan centrifugasi, semua antigen dan antibodi saling berikatan membentuk satu gumpalan aglutinasi yang besar dengan latar belakang jernih.

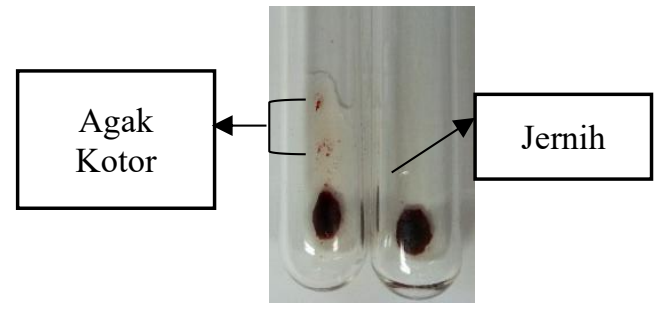

Gambar 2. Pemeriksaan Golongan Darah AB dengan Latar Belakang Agak Kotor dan Jernih

Pada golongan darah $\mathrm{AB}$ setelah dicentrifius membentuk satu gumpalan aglutinasi besar dengan latar belakang yang jernih namun juga ada yang agak kot kotor (kotorannya menempel pada dinding tabung).

Tabel 1. Hasil Pemeriksaan Golongan Darah AB 


\begin{tabular}{cccc}
\hline Konsentrasi & \multicolumn{2}{c}{ Latar Belakang } & Total \\
\cline { 2 - 3 } Suspensi Sel & Jernih & Kotor & Pemeriksaan \\
\hline $5 \%$ & $66,67 \%$ & $33,33 \%$ & 6 \\
$10 \%$ & $50 \%$ & $50 \%$ & 6 \\
$15 \%$ & 0 & $100 \%$ & 6 \\
$20 \%$ & 0 & $100 \%$ & 6 \\
\hline Total & & & 18 \\
\hline
\end{tabular}

Tabel 1. menunjukkan bahwa pada konsentrasi suspensi sel 5\% pemeriksaan golongan $\mathrm{AB}$ memiliki jumlah latar belakang jernih yang paling banyak yaitu 4 pemeriksaan, pada suspensi sel konsentrasi $10 \%$ ada 3 pemeriksaan, dan suspensi sel $15 \%$ dan $20 \%$ ada 0 pemeriksaan.

Tabel 2. Hasil Derajat Aglutinasi Berdasarkan Konsentrasi Suspensi Sel

\begin{tabular}{cccccccc}
\hline \multirow{2}{*}{$\begin{array}{c}\text { Konsentrasi } \\
\text { Suspensi Sel }\end{array}$} & Golongan & \multicolumn{5}{c}{ Derajat Aglutinasi } & \multirow{2}{*}{ Total } \\
\cline { 3 - 6 } & Darah & Negatif & $1+$ & $2+$ & $3+$ & $4+$ & \\
\hline $5 \%$ & $\mathrm{~A}$ & 0 & 0 & 0 & 0 & 6 & 6 \\
& $\mathrm{~B}$ & 0 & 0 & 0 & 0 & 6 & 6 \\
& $\mathrm{AB}$ & 0 & 0 & 0 & 0 & 6 & 6 \\
\hline $10 \%$ & $\mathrm{~A}$ & 0 & 0 & 0 & 0 & 6 & 6 \\
& $\mathrm{~B}$ & 0 & 0 & 0 & 0 & 6 & 6 \\
& $\mathrm{AB}$ & 0 & 0 & 0 & 0 & 6 & 6 \\
\hline $15 \%$ & $\mathrm{~A}$ & 0 & 0 & 0 & 0 & 6 & 6 \\
& $\mathrm{~B}$ & 0 & 0 & 0 & 0 & 6 & 6 \\
& $\mathrm{AB}$ & 0 & 0 & 0 & 0 & 6 & 6 \\
\hline $20 \%$ & $\mathrm{~A}$ & 0 & 0 & 0 & 0 & 6 & 6 \\
& $\mathrm{~B}$ & 0 & 0 & 0 & 0 & 6 & 6 \\
& $\mathrm{AB}$ & 0 & 0 & 0 & 0 & 6 & 6 \\
\hline & & 0 & 0 & 0 & 0 & 72 & 72 \\
\hline
\end{tabular}

Berdasarkan penelitian yang telah dilakukan, didapatkan semua hasil pemeriksaan golongan darah $\mathrm{A}, \mathrm{B}$, dan $\mathrm{AB}$ metode cell grouping dari suspensi sel konsentrasi $5 \%, 10 \%$, $15 \%$ dan $20 \%$ menunjukkan derajat aglutinasi $4+$, yaitu membentuk satu aglutinasi padat pada sel eritrosit.

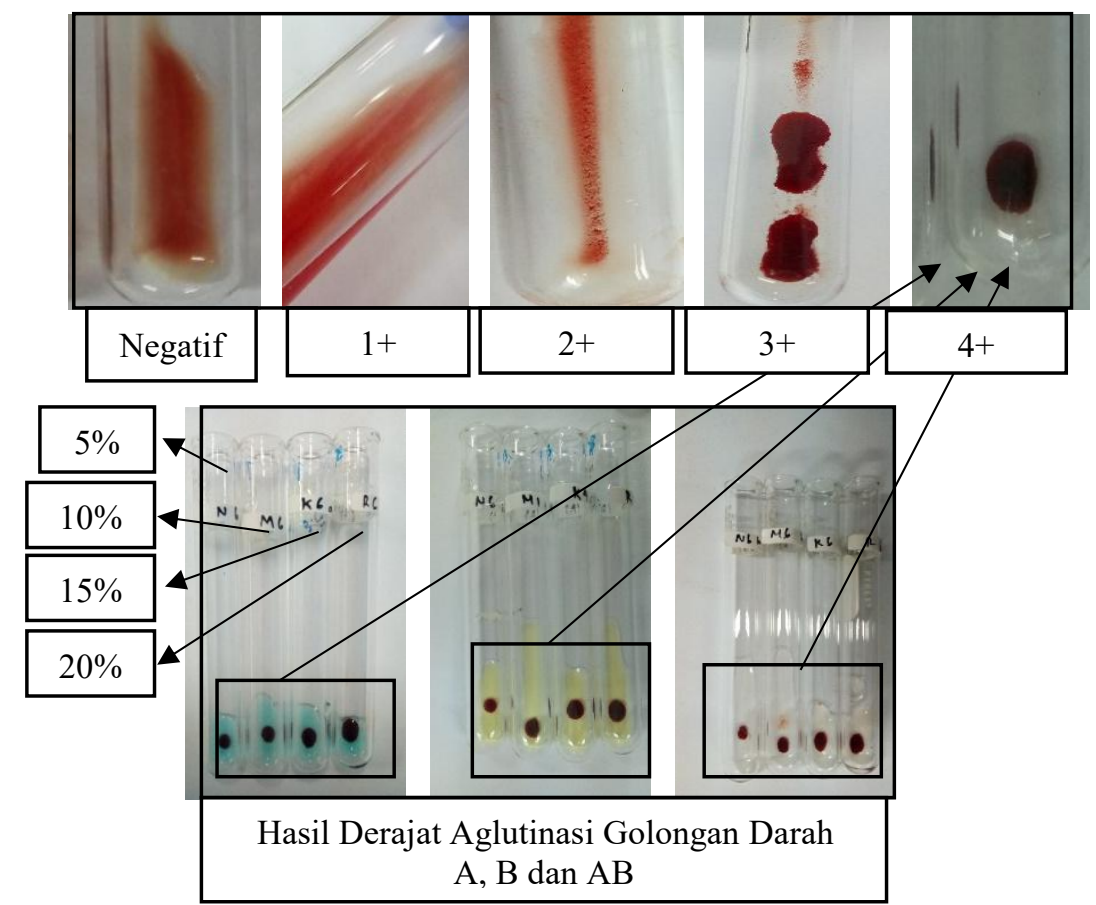


Gambar 2. (di halaman sebelumnya) Perbandingan Standar Derajat Aglutinasi (atas) dengan Hasil Penelitian (bawah) Secara Makroskopis

Gambar di atas menunjukkan bahwa hasil derajat aglutinasi yang didapat dari penelitian pemeriksaan golongan darah lebih mirip seperti gambar pada standar derajat aglutinasi 4+, yaitu membentuk satu aglutinasi padat yang menandakan bahwa derajat aglutinasi yang didapat adalah derajat aglutinasi $4+$.

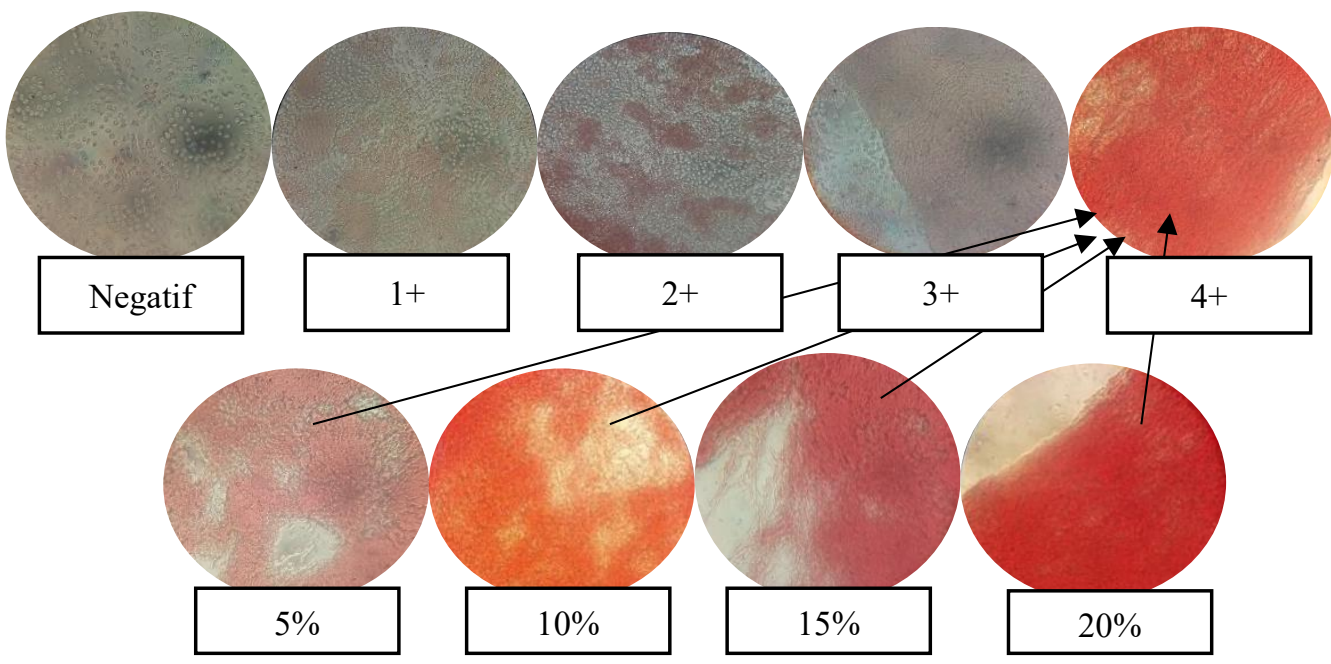

Gambar 3. Perbandingan Standar Derajat Aglutinasi (atas) Dengan (bawah) Hasil Penelitian Secara Mikroskopis Perbesaran 10x

Gambar di atas menunjukkan aglutinasi yang terbentuk dari hasil penelitian pemeriksaan golongan darah lebih mirip seperti gambar pada standar derajat aglutinasi 4+, yaitu terlihat aglutinasi besar dengan semua eritrosir yang membentuk ikatan aglutinasi yang terlihat seperti benang-benang.

Hasil terbentuknya derajat aglutinasi yang sama ini disebabkan karena jumlah antibodi yang terdapat di dalam reagen antisera jauh lebih banyak dibandingkan antigen yang ada di dalam suspensi sel dikarenakan pengenceran, sehingga semua antigen yang ada di dalam suspensi sel bisa berikatan dengan antibodi yang ada di dalam reagen antisera. Semakin banyak antigen-antibodi yang berikatan, akan membentuk aglutinasi yang semakin besar, jelas, dan semakin kuat reaksi yang terjadi (Faruq, 2015). Hasil penelitian ini sesuai dengan WHO (2013) bahwa konsentrasi suspensi sel tidak harus 5\%.

Hasil yang diperoleh dari penelitian ini ternyata tidak sesuai dengan hipotesa penelitian, yaitu adanya perbedaan derajat aglutinasi pada pemeriksaan golongan darah metode cell grouping berdasarkan tingkat konsentrasi suspensi sel, karena semua hasil penelitian menunjukkan derajat aglutinasi 4+. Hasil penelitian ini ternyata kurang sesuai dengan penjelasan WHO (2002), yang menjelaskan bahwa rasio serum terhadap sel eritrosit akan sangat mempengaruhi sensitifias dari tes aglutinasi.

WHO (2013) menginterpretasi hasil dari pemeriksaan golongan darah menggunakan suspensi sel 20\% akan membentuk derajat aglutinasi 3+ atau 4+. Pada tabel 4.1. memperlihatkan bahwa tidak ada konsentrasi suspensi sel yang lebih dominan membentuk derajat aglutinasi $4+$, karena semua hasil dari konsentrasi suspensi sel 5\%,10\%, 15\% dan $20 \%$ membentuk derajat aglutinasi $4+$.

Beberapa hasil pemeriksaan memperlihatkan bahwa $\backslash$ hasil pemeriksaan mungkin tidak terbentuk secara sempurna, contohnya pada pemeriksaan golongan darah AB. Hal ini bias dikarenakan muatan ion pada sel darah merah. Sel darah merah tidak pernah membuat kontak fisik langsung dengan satu sama lainnya baik di dalam tubuh (in vivo), atau dalam tabung reaksi (in vitro), hal ini dikarenakan tiap sel membawa muatan listrik negatif sehingga akan saling tolak-menolak. Ion-ion tersebut membentuk jarak diantara sel darah merah yang 
sangat kecil, sehingga cukup memadai untuk mencegah molekul-molekul IgG bisa melalui celah diantara sel-sel sehingga IgG hanya bisa menempel, menyelubungi atau mensensitisasinya ((Faruq, 2015), sehingga akan membentuk ikatan antigen antibodi yang tidak stabil.

Semua hasil derajat aglutinasi yang sama pada penelitian ini menunjukkan bahwa faktor konsentrasi suspensi sel pada metode cell grouping tidak berdampak pada derajat aglutinasi yang dibentuk, baik menggunakan konsentrasi suspensi sel 5\%, 10\%, 15\% dan 20\%. Hasil ini didapatkan karena dengan sel darah yang diencerkan, antibodi yang ada di dalam reagen antisera tetap bisa membentuk reaksi aglutinasi dengan semua antigen yang ada di dalam suspensi sel.

Semua data hasil penelitian ini didapatkan dalam bentuk kategori derajat aglutinasi yang sama, yaitu 4+, sehingga pengolahan data tidak dilanjutkan dengan uji beda menggunakan SPSS 16.0. Pengolahan data dilakukan dengan memasukkan data hasil penelitian ke dalam tabel hasil pengujian dan dianalisis secara langsung.

\section{Simpulan dan Saran}

\section{Simpulan}

Suspensi sel dengan konsenrasi 5\%, 10\%, 15\% dan 20\% menghasilkan derajat aglutinasi yang sama yaitu derajat aglutinasi $4+$ sehingga disimpulkan tidak ada perbedaan derajat aglutinasi pemeriksaan golongan darah metode cell grouping berdasarkan tingkat konsentrasi suspensi sel.

Pemeriksaan golongan darah golongan A dan B tidak menemukan konsentrasi suspensi derajat aglutinasi yang dominan menghasilkan derajat aglutinasi 4+, karena semua konsentrasi menghasilkan derajat aglutinasi dengan baik. Suspensi sel konsentrasi 5\% pada pemeriksaan golongan darah $\mathrm{AB}$ membentuk derajat aglutinasi 4+ dengan latar belakang lebih jernih sebanyak $70 \%$.

\section{Saran}

Bagi petugas laboratorium untuk memeriksaan golongan darah metode cell grouping sebaiknya diencerkan terlebih dahulu agar sel darah tidak terlalu pekat. Pemeriksaan dapat menggunakan suspensi sel dengan konsentrasi 5\%,10\%, 15\% dan $20 \%$ utuk pemeriksaan golongan darah $\mathrm{A}$ dan $\mathrm{B}$, dan menggunakan konsentrasi 5\% untuk pemeriksaan golongan darah AB.

Bagi peneliti lain dapat meneliti perbedaan derajat aglutinasi menggunakan variabel yang berkaitan dengan pengaruh konsentrasi suspensi sel di atas $20 \%$, kekuatan ion pada golongan darah $\mathrm{A}, \mathrm{B}$ dan $\mathrm{AB}$, dan pengaruh suhu penyimpanan sampel.

Bagi akademi bisa melakukan kegiatan pembelajaran menggunakan derajat aglutinasi dengan pengenceran terhadap reagen antisera golongan darah.

\section{Daftar Pustaka}

Bakta, I Made. 2012. Hematologi Klinik Ringkas. Jakarta: EGC.

Bima, Ariotejo. 2014. Laporan Pelatihan dokter baru UDD PMI 2014. Malang. Retrieved January 8, 2018, from https://bimaariotejo.wordpress.com/category/darah/

Budiningsih, Asri. 2010. Gambaran Faktor-Faktor Yang Memengaruhi Motivasi Pendonor Sukarela Untuk Mendonorkan Darah Di Utd-Pmi Kota Medan Tahun 2010. Retrieved January $8, \quad 2018$, from http://repository.usu.ac.id/bitstream/handle/123456789/33673/Chapter\%20II.pdf?sequen $\mathrm{ce}=4$

Dahlan, Muhammad Sopiyudin. 2011. Statistik untuk Kedokteran dan Kesehatan: Deskriptif, Bivariat, dan Multivariat, Dilengkapi Aplikasi dengan Menggunakan SPSS Edisi 5. Jakarta: Salemba Medika. 
Departemen Kesehatan RI. 2008. Pedoman Pembinaan dan Pengawasan Pelayanan Darah oleh Dinas Kesehatan. Jakarta: Lampiran Departemen Kesehatan RI. Retrieved January 7, 2018 from http://perpustakaan.depkes.go.id:8180/bitstream//123456789/824/4/BK2008-G16.pdf

Faruq, Zulfikar Husni. 2015. Modul 3: Serologi Golongan Darah. Banten: Poltekkes Jakarta 3.

Kiswari, Rukman. 2014. Hematologi \& Transfusil. Jakarta: Erlangga.

Kitchen, Gareth. 2008. Immunology and haematology. China: Elsevier.

Kosasih, E.N., A.S. Kosasoh. 2008. Tafsiran Hasil Pemeriksaan Laboratorium Klinik. Tangerang: KARISMA Publishing Group.

Kresno, Siti Boedina. 1988. Pengantar Hematologi dan Imunohematologi. Jakarta: Gaya Baru.

Mutiawati, Vivi Keumala. 2013. Perbedaan Derajat Aglutinasi Pemeriksaan Golongan Darah Antara Eritrosit Tanpa Pencucian dengan Eritrosit Tanpa Pencucian Pada Penderita Talasemia. Retrieved November 19, 2017, from http://download.portalgaruda.org/article.php?article=428872\&val=3947\&title=PERBED AAN\%20DERAJAT\%20AGLUTINASI\%20PEMERIKSAAN\%20GOLONGAN\%20D ARAH\%20ANTARA\%20ERITROSIT\%20TANPA\%20PENCUCIAN\%20DENGAN\% 20PENCUCIAN\%20PADA\%20PENDERITA\%20TALASEMIA

Penn Vet Research. 2016. Penn Vet Research Shows Success for New Testing Methods for Blood Compatibility, Typing. Retrieved January 8, 2018, from http://www.vet.upenn.edu/about/press-room/publications/new-bolton-post/new-bolton-p ost-summer-2016/penn-vet-research-shows-success-for-new-testing-methods-for-bloodcompatibility-typing

Peraturan Menteri Kesehatan Republik Indonesia Nomor 83. 2014. Unit Transfusi Darah, Bank Darah Rumah Sakit, dan Jejaring Pelayanan Transfusi Darah. Retrieved December 17, 2017

Peraturan Pemerintah Republik Indonesia Nomor 7. 2011. Pelayanan Darah. Retrieved January 4, 2018

Samudra, Riska Indriati. 2017. Perbedaan Derajat Aglutinasi Berdasarkan Lama Penyimpanan Suspensi Sel Pada Pemeriksaan Golongan Darah Metode Tabung. Unpublished undergraduate diploma, Poltekkes Kemenkes Semarang, Semarang.

Siswanto, Susila, \& Suyanto. 2016. Metodologi Penelitian Kesehatan DAN Kedokteran. Yogyakarta: Bursa Ilmu.

Soemantri, Ag, Tatty Ermin Setiati. 2009. Kegawatan Hematologi. Semarang: Pelita Insani. Yuni, Natalia Erlina. 2015. Kelainan Darah. Yogyakarta: Nuha Medika.

WHO. 2002. Model Standard Operating Procedures for Blood Transfusion service. New Delhi: WHO. Retrieved January 4, 2018, from http://apps.searo.who.int/PDS DOCS/B0235.pdf?ua $=1$

WHO. 2013. Standard Operating Procedures for Blood Transfusion. Bangladesh: WHO. Retrieved January 4, 2018, from http://www.who.int/bloodsafety/transfusion_services/sop-bts bangladesh.pdf 